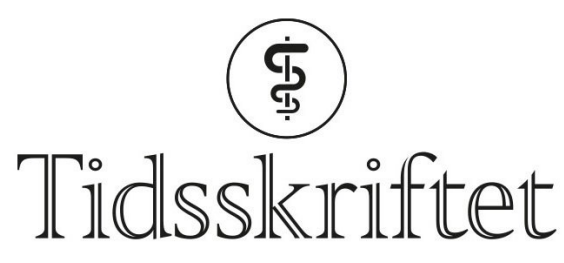

DEN NORSKE LEGEFORENING

\title{
Ikke ytterligere inhalasjonssteroider ved astmaforverring
}

KRONIKK

\section{INGA MARTHE GRØNSETH}

E-post: i.m.gronseth@gmail.com

Inga Marthe Grønseth er allmennlege i spesialisering ved RELIS Midt-Norge og Avdeling for klinisk farmakologi, St. Olavs hospital.

Forfatter har fylt ut ICMJE-skjemaet og oppgir ingen interessekonflikter.

\section{TORBJØRN NAG}

Torbjørn Nag er spesialist i barnesykdommer og overlege ved Klinikk for kvinner, barn og ungdom, Ålesund sjukehus.

Forfatter har fylt ut ICMJE-skjemaet og oppgir ingen interessekonflikter.

\section{PÅ-DIDRIK HOFF ROLAND}

Pål-Didrik Hoff Roland er cand.pharm. og legemiddelrådgiver ved RELIS Midt-Norge, Avdeling for klinisk farmakologi, St. Olavs hospital.

Forfatter har fylt ut ICMJE-skjemaet og oppgir ingen interessekonflikter.

I flere tiår har midlertidig $\varnothing$ kning i dosen av inhalasjonssteroider ved astmaforverringer vært vanlig praksis i Norge. For de fleste gir dette ingen effekt, men derimot $\varnothing \mathrm{kt}$ bivirkningsrisiko. Denne praksisen bør derfor endres.

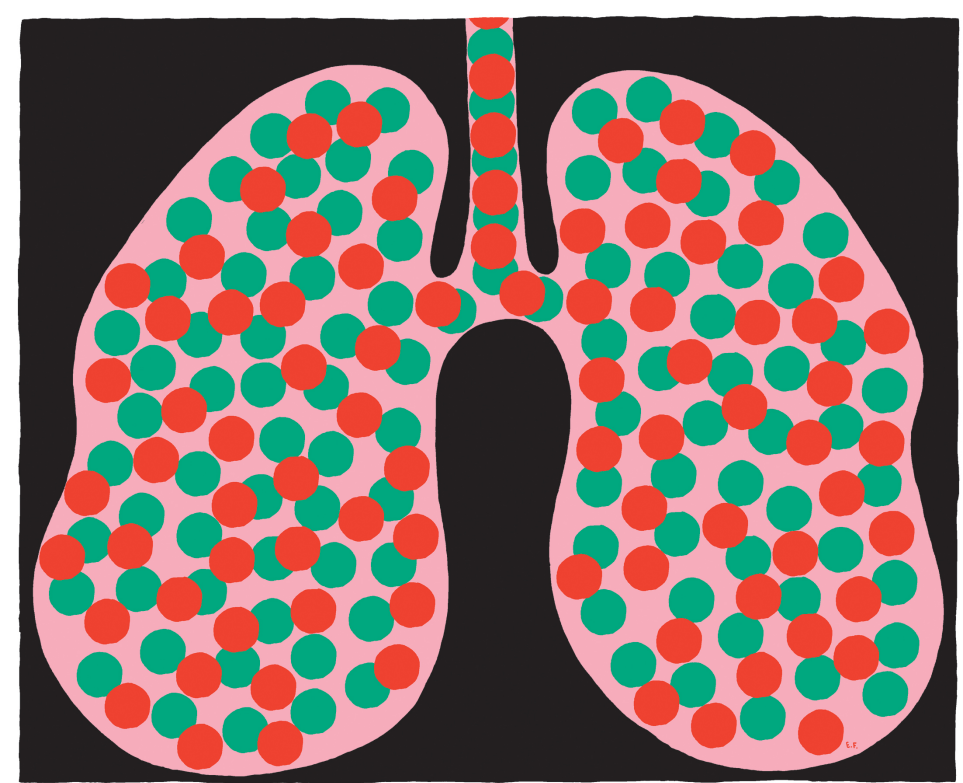

Illustrasjon: Espen Friberg 
Inhalasjonssteroider har vært brukt til behandling av astma i over 40 år. De er vist å kunne bedre funksjonsnivå og redusere anfallsfrekvens hos pasienter med alle grader av astma (1) og er fortsatt vårt viktigste forebyggende medikament. Denne teksten omhandler midlertidig doseøkning av inhalasjonssteroider ved astmaforverringer (astmaeksaserbasjoner) hos voksne og barn. Doseøkning ved kronisk underbehandlet astma, intermitterende behandling og $ø$ kning av kombinasjonspreparater faller ikke inn under dette.

Inhalasjonssteroider reduserer inflammasjon i luftveiene blant annet gjennom aktivering og deaktivering av inflammasjonsgener, stabilisering av inflammasjonsceller samt oppregulering av mengde og funksjon av beta-2-reseptorer (2). Gitt som inhalasjon har steroider generelt lite bivirkninger. Lokale bivirkninger som soppinfeksjon i munnhulen, faryngolaryngeal irritasjon og heshet ses hyppig. Hos barn ser man noe lavere veksthastighet og en sannsynlig lett reduksjon i slutthøyde (3). Ved langvarig bruk og høye doser $ø$ ker risikoen for systemiske bivirkninger som binyrebarksvikt, og i sjeldnere tilfeller redusert bentetthet, katarakt (grå stær) og glaukom (grønn stær).

En strategi med midlertidig dobling av dosen inhalasjonssteroider ved astmaforverringer ble blant annet anbefalt i British Asthma Guidelines fra 1995. Man håpet at dette kunne forkorte og redusere alvorligheten av episodene. Det ble bemerket at det ikke fantes studier på dette (4).

En uformell forespørsel til norske fastleger i mai 2018 viste at midlertidig dobling av dosen inhalasjonssteroider er vanlig praksis hos et stort flertall av fastlegene.

\section{Dobling av inhalasjonssteroider}

Allerede i 2004 ble det publisert to randomiserte placebokontrollerte studier som sådde betydelig tvil rundt praksisen med dobling av inhalasjonssteroider $(5,6)$. I 2016 ble det publisert en Cochrane-kunnskapsoppsummering der det ble konkludert med at det er lite sannsynlig at en $ø \mathrm{kt}$ dose inhalasjonssteroider reduserer behovet for systemiske steroider, reduserer innleggelser eller forkorter sykdomsforløpet (7). Oppsummeringen omfattet åtte studier med totalt 1669 pasienter. Tre av studiene omhandlet barn.

\section{Mangedobling av inhalasjonssteroider}

British Thoracic Society (BTS) og Global Initiative for Asthma (GINA) anbefaler ikke lenger i sine retningslinjer å øke dosen inhalasjonssteroider ved forverringer hos barn under fem år $(8,9)$. For pasienter over fem år har Global Initiative for Asthma beholdt en anbefaling om minst å doble dosen inhalasjonssteroider ved forverring. De baserer dette blant annet på flere mindre studier som kan tyde på effekt av mangedobling (8).

For å undersøke effekten av en firedobling ble en større randomisert ikke-blindet studie satt opp av National Institute for Health Research i England. Artikkelen ble publisert i New England Journal of Medicine i mars 2018 (10). I denne studien ble 1922 pasienter med astma fra 16 år og oppover randomisert til to grupper. Den ene gruppen fikk firedoblet sin vanlige dose inhalasjonssteroider ved begynnende astmaforverring, enten med sin vanlige inhalator eller med tillegg av en annen inhalator for pasienter som fikk kombinasjonsbehandling. Den økte dosen ble kontinuert til normalisering av symptomer eller toppstrømshastighet (peak flow), eller i maksimalt 14 dager. Den andre gruppen $ø$ kte ikke dosen ved begynnende forverring. På forhånd ble en $30 \%$ reduksjon av alvorlige forverringer definert som et klinisk betydningsfullt funn. I studien fant man en statistisk signifikant $19 \%$ reduksjon i alvorlige forverringer hos pasientene som firedoblet dosen inhalasjonssteroider. Antall som må behandles (number needed to treat) var 15 for å hindre en forverring. Det ble registrert bivirkninger hos $7 \%$ i gruppen som firedoblet, mot $2 \% \mathrm{i}$ kontrollgruppen. Bivirkningene var primært soppinfeksjoner og dysfoni.

I en annen studie publisert i New England Journal of Medicine i mars 2018 ble effekten av femdobling av inhalasjonssteroider ved begynnende astmaforverring hos barn unders $\varnothing \mathrm{kt}$ 


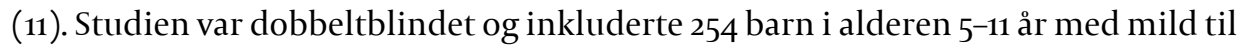
moderat astma og som hadde hatt minst én forverring behandlet med systemiske steroider foregående år. Primærendepunktet var andelen forverringer som måtte behandles med systemiske steroider. Forfatterne konkluderte med at femdobling av dosen ved en begynnende astmaforverring ikke reduserte andelen alvorlige forverringer, bedret symptomskår eller reduserte bruken av salbutamol. Det ble også funnet en mulig sammenheng mellom femdobling av dosen inhalasjonssteroider og redusert lengdevekst, spesielt hos de minste barna (statistisk signifikant i gruppen 5-7 år).

De to studiene $(10,11)$ tok begge for seg mangedobling av inhalasjonssteroider, men de har også noen klare forskjeller. Det er mulig at både alder, blinding og alvorlighet har spilt inn på resultatene. Etterlevelse er trolig det største problemet i behandlingen av astma. Det anslås at minst 50 \% ikke tar behandlingen som forskrevet, i alle fall store deler av tiden ( 8 , 9). I studien på barn var det strenge krav til etterlevelse for å delta (11). $190 \mathrm{av} 444$ barn ble ekskludert grunnet etterlevelse $<75 \%$. Daglige registreringer viste da svært god etterlevelse i studieperioden, og dette kan være en mulig forklaring på at barnegruppen generelt var mye friskere enn forventet i studieperioden. Studien på voksne (10) var åpen og konstruert for å være mest mulig lik det reelle liv, uten at man tok hensyn til etterlevelse. Etterlevelse bedres med $ø$ kende sykdomsaktivitet, og det er mulig at resultatet viser pasienter som tar firedobbel dose intermitterende, men som ellers har dårlig etterlevelse. Det er også verdt å merke seg at pasientene i voksenstudien dels tar så høye doser inhalasjonssteroider at en firedobling forventes å ha systemiske effekter lik behandling med prednisolon (10).

\section{Retningslinjer}

British Thoracic Societys og Global Initiative for Asthmas retningslinjer, BMJ Best Practice og UptoDate samt flere norske kilder anbefaler alle å øke frekvens og dose av korttidsvirkende beta-2-agonister som primær behandling ved astmaforverringer ( 8,9 , 12-16). Doseringen tilpasses alder og alvorlighetsgrad. Ipratropiumbromid kan legges til ved manglende effekt av korttidsvirkende beta-2-agonister alene. Både hos voksne og barn anbefales korte kurer med perorale steroider i de tilfellene der man ikke kommer i mål med intensiv beta-2-agonistbehandling etter gjeldende retningslinjer $(8,9,12-16)$. Hos barn er bivirkninger av systemiske steroider relativt vanlig, og bruken bør begrenses til de tilfeller der diagnosen atopisk astma er sannsynlig og der man antar at slik behandling vil redusere behovet for sykehusinnleggelse (17).

Alvorlige astmaforverringer, eller forverringer som ikke responderer tilfredsstillende på ovenstående behandling skal behandles på sykehus.

\section{Våre anbefalinger}

Det finnes per i dag ikke overbevisende dokumentasjon for å øke dosen inhalasjonssteroider ved begynnende astmaforverringer, verken for voksne eller barn. Hos enkelte voksne med sannsynlig dårlig etterlevelse kan denne strategien likevel vurderes. Effekten er sannsynligvis beskjeden, og terskelen bør være lav for overgang til en kortvarig kur med perorale steroider ved forverring.

Hos barn er økt dose av inhalasjonssteroider assosiert med redusert lengdevekst, og det er ingen dokumentert effekt ved god etterlevelse. Doseøkning ved forverringer bør derfor ikke benyttes.

Hos alle pasienter med astma bør man vurdere etterlevelse og teknikk på hver kontroll. 
2. Barnes PJ. Molecular effects of inhaled glucocorticoid therapy in asthma. UpToDate Versjon 8.o. https://www.uptodate.com/contents/molecular-effects-of-inhaled-glucocorticoid-therapy-in-asthma (15.6.2018).

3. Zang L, Prietsch S, Ducharme F. Inhaled corticosteroids in children with asthma: Effect on growth. Cochrane Database Syst Rev 2014; 7: CDoog471.

4. British Thoracic Society, Scottish Intercollegiate Guidelines Network. The British Guidelines on Asthma Management. Thorax 1997; 52 (suppl 1):1-21.

5. Harrison TW, Oborne J, Newton S et al. Doubling the dose of inhaled corticosteroid to prevent asthma exacerbations: randomised controlled trial. Lancet 2004; 363: 271-5. [PubMed][CrossRef]

6. FitzGerald JM, Becker A, Sears MR et al. Doubling the dose of budesonide versus maintenance treatment in asthma exacerbations. Thorax 2004; 59: 550-6. [PubMed][CrossRef]

7. Kew KM, Quinn M, Quon BS et al. Increased versus stable doses of inhaled corticosteroids for exacerbations of chronic asthma in adults and children. Cochrane Database Syst Rev 2016; 6: CDoo7524. [PubMed]

8. Global initiative for asthma (GINA). Global strategy for asthma management and prevention 2018. https://ginasthma.org/wp-content/uploads/2018/o4/wms-GINA-2018-report-V1.3-002.pdf(15.6.2018)

9. British Thoracic Society, Scottish Intercollegiate Guidelines Network. British Guideline on the Management of Asthma 2016. https://www.brit-thoracic.org.uk/standards-of-care/guidelines/ (15.6.2018).

10. McKeever T, Mortimer K, Wilson A et al. Quadrupling inhaled glucocorticoid dose to abort asthma exacerbations. N Engl J Med 2018; 378: 902-10. [PubMed][CrossRef]

11. Jackson DJ, Bacharier LB, Mauger DT et al. Quintupling inhaled glucocorticoids to prevent childhood asthma exacerbations. N Engl J Med 2018; 378: 891-901. [PubMed][CrossRef]

12. Jost PD. Astma, akutt, ungdom ( $\geq 12$ år) og voksen. I: Norsk elektronisk legehåndbok. https://www.legehandboka.no (15.6.2018).

13. Fanta $\mathrm{CH}$. Management of acute exacerbations of asthma in adults. UpToDate versjon 49.o. https://www.uptodate.com/contents/management-of-acute-exacerbations-of-asthma-in-adults (9.4.2018).

14. Robinson PD, Chang A. Acute asthma exacerbation in children. BMJ Best Practice. https://www.bestpractice.bmj.com/topics/en-gb/1098 (15.6.2018).

15. Majumdar S. Acute asthma exacerbation in adults. BMJ Best Practice. https://www.bestpractice.bmj.com/topics/en-gb/45(15.6.2018).

16. Nag T, Øymar K, Crowley S et al. Akutt astma bronkiale. I: Akuttveileder i pediatri 2018. https://www.helsebiblioteket.no/retningslinjer/akuttveileder-i-pediatri/ (19.11.2018).

17. Øymar K, Mikalsen IB, Nag T et al. Systemiske steroider til førskolebarn med symptomer fra nedre luftveier. Tidsskr Nor Legeforen 2017; 137: 698-9. [PubMed][CrossRef]

Publisert: 21. februar 2019. Tidsskr Nor Legeforen. DOI: 10.4045/tidsskr.18.0537

Mottatt 21.6.2018, første revisjon innsendt 20.11.2018, godkjent 3.12.2018.

(C) Tidsskrift for Den norske legeforening 2020. Lastet ned fra tidsskriftet.no 